\title{
PENGARUH KEBIJAKAN DIVIDEN TERHADAP HARGA SAHAM \\ PERUSAHAAN SUB SEKTOR OTOMOTIF DAN KOMPONEN YANG TERDAFTAR DI BURSA EFEK INDONESIA PERIODE 2008-2017
}

\author{
Cut Ermiati ${ }^{1)}$, Dita Amanah' ${ }^{2}$, \\ Dedy Ansari Harahap" ${ }^{3)}$ Eva Santi Siregar ${ }^{4)}$ \\ ${ }^{1,2,4)}$ Fakultas Ekonomi Universitas Negeri Medan \\ ${ }^{3)}$ Fakultas Ekonomi Universitas Islam Sumatera Utara \\ ${ }^{1)}$ c.ermiati@gmail.com \\ 2)ditamnh@yahoo.com \\ 3)deanhar@yahoo.com \\ ${ }^{4)}$ eva.santisiregar@gmail.com
}

\begin{abstract}
Penelitian ini bertujuan untuk mengetahui pengaruh dividend payout ratio terhadap dividend yield, pengaruh dividend payout ratio terhadap harga saham dan pengaruh dividend yield terhadap harga saham pada perusahaan sub sektor otomotif dan komponen yang terdaftar di Bursa Efek Indonesia pada Tahun 2008-2017. Populasi yang digunakan dalam penelitian ini adalah perusahaan sub sektor otomotif dan komponen yang terdaftar di Bursa Efek Indonesia pada tahun 2008 - 2017 dimana jumlah populasi yang digunakan sebanyak 12 perusahaan. Teknik pengambilan sampel yang digunakan adalah purposive sampling sehingga sampel dalam penelitian ini sebanyak 3 perusahaan. Teknik analisis data yang digunakan adalah analisis regresi berganda dengan menggunakan SPSS 23. Uji hipotesis menunjukkan dividend payout ratio berpengaruh signifikan terhadap harga saham dan dividend yield berpengaruh signifikan terhadap harga saham.
\end{abstract}

Kata kunci : Dividend Payout Ratio, Dividend Yield, Harga Saham. 


\section{PENDAHULUAN}

Perusahaan otomotif dan komponen merupakan salah satu perusahaan sub sektor di Bursa Efek Indonesia yang semakin bertumbuh dan berkembang di Indonesia. Hal ini terlihat dari banyaknya produk- produk otomotif dan komponen yang digunakan baik dari jenis maupun jumlahnya. Disamping

perkembangan produknya, terdapat permintaan produk otomotif dimasyarakat contohnya seperti kendaraan roda empat dan kendaraan roda.

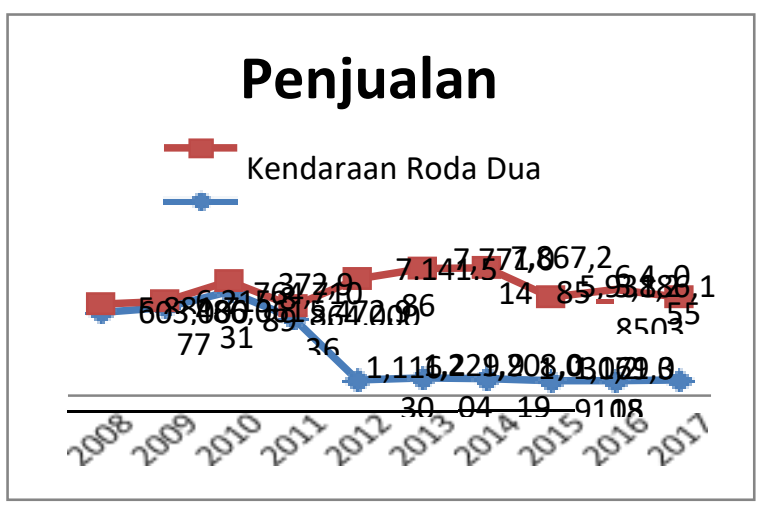

Sumber: Gakindo \& Aisi

Gambar 1 Penjualan Kendaraan Roda 2

Penjualan Kendaraan Roda Empat Dan Dua Perusahan Otomotif Dan Komponen Tahun 2008-2017

Pada Gambar 1 di atas terlihat bahwa penjualan kendaraan roda empat dan dua perusahaan otomotif dan komponen mengalami naik turun. Penjualan pada kendaraan roda dua terlihat tiga tahun mengalami peningkatan di tahun 2012, 2013 dan 2014 dan kemudian tahun 2015 menurun, sedangkan tahun 2016 mengalami peningkatan kembali dan kemudian penjualan mengalami penurunan pada tahun 2017. Sedangkan penjualan kendaraan roda empat terlihat pada tahun 2009 dan 2010 mengalami peningkatan sedangkaan dari tahun 2012 sampai 2017 penjualan terus menurun tetapi tahun 2016 dan 2017 mengalami sedikit kenaikan dari tahun 2015 walau tidak sebanding pada tahun 2010. Naik turunnya penjualan kendaraan roda empat dan dua ini dipengaruhi oleh permintaan masyarakat yang naik turun pula, meski pun demikian kondisi industri otomotif dan komponen dikatakan masih tetap tumbuh.

Perkembangan industri otomotif dan komponen ini menarik para investor untuk melakukan investasi. Sebelum melakukan investasi para investor perlu melakukan penilaian yang baik untuk mengetahui dan
NIAGAWAN Vol 8 No 2 Juli 2019

memilih saham perusahaan tersebut. Tujuan investor membeli saham perusahaan pada hakekatnya bertujuan menerima dividen dan capital gain. Dalam berinvestasi faktor yang sangat penting dan harus diperhatikan oleh investor adalah harga saham karena pergerakan harga saham merupakan prestasi atau kinerja yang ditunjukkan oleh perusahaan tersebut. Dengan pergerakan harga saham yang cenderung bergerak naik dari waktu ke waktu , maka para investor akan memperoleh keuntungan dan juga meningkatkan kepercayaan investor pada perusahaan atas kenaikkan tersebut.

Untuk melihat tinggi rendahnya pergerakan harga saham perusahaan tersebut dapat menggunakan Indeks Harga Saham (IHS). Indeks Harga Saham (IHS) merupakan indikator yang menggambarkan suatu pergerakan harga saham. Indeks Harga Saham (IHS) ini berfungsi sebagai tren pasar, artinya pergerakan indeks menggambarkan kondisi pasar pada suatu saat, apakah pasar aktif atau lesu.

Pergerakan naik dan turunnya harga saham pada setiap perusahaan terjadi karena adanya beberapa faktor yang mempengaruhinya. Faktor- faktor yang dapat mempengaruhi harga saham antara lain berupa laba per lembar saham (EPS), tingkat bunga, kebijakan dividen, jumlah laba yang didapat perusahaan, tingkat resiko dan pengembalian. Dari beberapa faktor yang mempengaruhi harga saham salah satunya kebijakan dividen. Kebijakan dividen adalah keputusan apakah laba yang dihasilkan perusahaan pada akhir periode dibagikan kepada para pemilik saham sebagai dividen atau laba tersebut ditahan sebagai penambah modal perusahaan yang akan digunakan dalam kegiatan, atau investasi pengembangan perusahaan dimasa datang. Perusahaan yang mengambil keputusan laba yang dihasilkan dibagikan sebagai dividen kepada para pemegang saham merupakan sinyal bagi investor. Bagi investor pembagian dividen yang stabil atau tinggi merupakan indikator prospek perusahaan yang stabil atau tinggi pula dengan demikian risiko perusahaan juga relative lebih rendah dibandingkan dengan perusahaan yang membagikan dividen tidak stabil dan kecil. Dividen merupakan salah satu faktor yang menarik bagi investor sehingga dapat mempengaruhi harga saham. Indikator kebijakan dividen yang digunakan yaitu Dividend Payout Ratio (DPR) dan Dividend Yield (DY). 


\section{TINJAUAN PUSTAKA Harga Saham}

Menurut Hadi (2013: 67) saham adalah suatu surat berharga yang dapat dibeli atau dijual oleh perorangan atau lembaga di pasar tempat surat berharga tersebut diperjual-belikan.

Menurut Jogiyanto (2011: 143) harga saham adalah harga saham yang terjadi di pasar bursa pada saat tertentu yang ditentukan oleh pelaku pasar. Tinggi rendahnya harga saham ini ditentukan oleh permintaan dan penawaran saham tersebut di pasar modal.

\section{Indeks Harga Saham}

Indeks harga saham merupakan suatu indikator yang menunjukkan pergerakan harga saham. Pergerakan indeks menggambarkan kondisi pasar waktu ke waktu, apakah harga saham sedang naik atau turun. Indeks harga saham menjadi indikator bagi investor untuk pengambilan keputusan investasi (Hariyani, 2010:268).

Keuntungan memiliki saham adalah investor dapat memperoleh dividen dan capital gain, sedangkan risikonya adalah tidak mendapatkan dividen dan capital loss. Dengan adanya keuntungan dan risiko dari kepemilikan saham, investor harus pandai dalam melakukan analisis sebelum memutuskan untuk berinvestasi pada saham supaya dapat meminimalisir risiko dari kepemilikan saham tersebut.

\section{Dividen}

Menurut Musthafa (2017: 141) dividen adalah bagian keuntungan yang diterima oleh pemegang saham dari suatu perusahaan.

Kebijakan Dividen

Menurut Mulyawan (2015: 253)

Kebijakan dividen merupakan keputusan untuk membagi laba yang diperoleh perusahaan kepada pemegang saham sebagai dividen atau akan menahan dalam bentuk laba ditahan untuk digunakan sebagai pembiayaan investasi pada masa yang akan datang.

$$
\text { Kebijakan dividen menyediakan }
$$
informasi mengenai performa perusahaan. Informasi mengenai dividen akan mempengaruhi permintaan dan penawaran saham perusahaan di pasar modal, yang kemudian akan berpengaruh terhadap harga saham. Apabila manajer keuangan berhasil membuat kebijakan dividen dengan tepat, terutama memberikan dividen kepada para pemegang saham secara teratur dan meningkat, maka investor akan merespon positif
NIAGAWAN Vol 8 No 2 Juli 2019

sinyal tersebut dan harga saham akan meningkat (Yudiana, 2013: 221).

Kebijkan dividen dalam penelitian ini menggunakan dua indikator yaitu Dividen payout ratio (DPR) dan Dividen Yield (DY). Dividen payout ratio (DPR) digunakan sebagai cara pengestimasian dividen untuk periode yang akan datang, sedangkan Dividen Yield (DY) digunakan sebagai suatu ukuran risiko dan sebagai suatu penyaring investasi (Hanafi, 2013: 368).

\section{Dividen payout ratio (DPR)}

Menurut Gumanti (2013: 23) Dividen payout ratio (DPR) atau Rasio pembayaran dividen diukur dengan cara membagi besarnya dividen per lembar saham dengan laba bersih per lembar saham. Rasio pembayaran dividen digunakan dalam berbagai situasi. Misalnya, rasio tersebut digunakan dalam penelitian sebagai suatu cara untuk menduga besarnya dividen di tahun mendatang.

Kenaikan rasio pembayaran dividen (DPR) dapat diinterprestasikan sebagai informasi bahwa perusahaan memiliki profitabilitas masa depan yang baik (berita baik= good news), dan karenanya harga saham perusahaan akan bereaksi positif (naik). Demikian juga halnya, pengurangan dividen atau pemotongan dividen mungkin dianggap sebgai sinyal bahwa profitabilitas perusahaan dimasa depan tidak baik atau buruk, dan karenanya harga saham akan cenderung turun. (Gumanti, 2013: 64-65).

Dividend Yield (DY)

Menurut Gumanti (2013:22) Dividen yield menjadi penting untuk dipahami karena menyiratkan ukuran bahwa komponen dari return total disumbang oleh dividen. Artinya, dalam menghitung return total investor harus memasukkan unsur besarnya dividen yang diterima selain selisih harga saham antara awal dan akhir kepemilikan.

Besarnya hasil dividen menunjukkan besarnya pengembalian yang diperoleh investor dari dividen yang dialokasikan oleh perusahaan. Jika dividen yield (DY) semakin besar ini berarti perusahaan tersebut dinilai kinerjanya baik oleh para investor, sehingga akan menarik minat para investor untuk membeli saham dari perusahaan tersebut dan menyebabkan harga saham perusahaan tersebut naik (Warsono, 2012: 38). 


\section{METODE PENELITIAN}

Populasi

Populasi dalam penelitian ini adalah perusahaan sub sektor otomotif dan komponen yang tercatat di Bursa Efek Indonesia selama tahun 2008-2017 yang berjumlah 12 perusahaan.

Tabel 1 Daftar Perusahaan yang Menjadi Populasi Penelitian

\begin{tabular}{|c|c|c|}
\hline No & $\begin{array}{l}\text { Kode } \\
\text { Perusahaan }\end{array}$ & $\begin{array}{l}\text { Nama } \\
\text { Perusahaan }\end{array}$ \\
\hline 1. & ASII & $\begin{array}{l}\text { PT. } \quad \text { Astra } \\
\text { Internasional Tbk }\end{array}$ \\
\hline 2. & AUTO & $\begin{array}{l}\text { PT. Astra } \\
\text { Otoparts Tbk }\end{array}$ \\
\hline 3. & SMSM & $\begin{array}{l}\text { PT. } \quad \text { Selamat } \\
\text { Sempurna Tbk }\end{array}$ \\
\hline 4. & BRAM & $\begin{array}{l}\text { PT. Indo Kodrsa } \\
\text { Tbk }\end{array}$ \\
\hline 5. & GDYR & $\begin{array}{l}\text { PT. Goodyear } \\
\text { Indonesia Tbk }\end{array}$ \\
\hline 6. & GJTL & $\begin{array}{l}\text { PT. Gajah } \\
\text { Tunggal Tbk }\end{array}$ \\
\hline 7. & IMAS & $\begin{array}{lc}\text { PT. } & \text { Indomobil } \\
\text { Sukses } & \text { Internasional } \\
\text { Tbk } & \end{array}$ \\
\hline 8. & INDS & $\begin{array}{ll}\text { PT. } & \text { Indospring } \\
\text { Tbk } & \end{array}$ \\
\hline 9. & LPIN & $\begin{array}{l}\text { PT. Multi Prima } \\
\text { Sejahtera Tbk }\end{array}$ \\
\hline 10. & MASA & $\begin{array}{l}\text { PT. Multistrada } \\
\text { Arah } \quad \text { Sarana Tbk }\end{array}$ \\
\hline 11. & NIPS & PT. Nipress Tbk \\
\hline 12. & PRAS & $\begin{array}{l}\text { PT. Prima Alloy } \\
\text { Steel Universal Tbk }\end{array}$ \\
\hline
\end{tabular}

Sampel

Pemilihan sampel dalam penelitian ini menggunakan metode purposive sampling yaitu teknik pengambilan sampel penelitian berdasarkan kriteria-kriteria tertentu, dengan tujuan untuk mendapatkan sampel yang representatif sesuai dengan kriteria yang ditentukan. Kriteria-kriteria yang digunakan untuk pengambilan sampel dalam penelitian adalah sebagai berikut:

Sampel yang dipilih adalah perusahaan sub sektor otomotif dan komponen yang terdaftar di BEI sejak tahun 2008 dan tetap terdaftar di BEI hingga tahun 2017. Hal ini dimaksudkan untuk data yang
NIAGAWAN Vol 8 No 2 Juli 2019

berkesinambungan. Perusahaan yang menjadi sampel adalah perusahaan yang menerbitkan laporan keuangan dari tahun 2008-2017. Perusahaan yang menjadi sampel adalah perusahaan yang membagikan dividen tunai kepada pemegang saham pada tahun 2008-2017. Berdasarkan analisis pemilihan sampel dengan kriteria di atas, ada 3 perusahaan yang memenuhi kriteria yang digunakan dalam penelitian ini. Perusahaan-perusahaan tersebut ditunjukkan pada Tabel 2 berikut ini.

Tabel 2 Daftar Perusahaan yang Menjadi Sampel Penelitian

\begin{tabular}{|l|l|l|}
\hline No & $\begin{array}{l}\text { Kode } \\
\text { Perusahaan }\end{array}$ & $\begin{array}{l}\text { Nama } \\
\text { Perusahaan }\end{array}$ \\
\hline 1. & ASII & $\begin{array}{l}\text { PT. Astra } \\
\text { Internasional Tbk }\end{array}$ \\
\hline 2. & AUTO & $\begin{array}{l}\text { PT. Astra } \\
\text { Otoparts Tbk }\end{array}$ \\
\hline 3. & SMSM & $\begin{array}{l}\text { PT. Selamat } \\
\text { Sempurna Tbk }\end{array}$ \\
\hline
\end{tabular}


Defenisi Operasional

Harga saham (Y)

Harga saham merupakan harga yang terjadi di pasar bursa yang ditentukan oleh pelaku pasar yang terjadi dan ditentukan oleh permintaan dan penawaran saham yang bersangkutan dipasar modal. Harga saham dalam penelitian ini dilihat dari Indeks Harga Saham yaitu merupakan indikator perubahan harga suatu saham dibandingkan dengan harga perdananya dengan periode waktu dari tahun 2008-2017 pada perusahaan sub sektor industri otomotif dan komponen.

Dividend Payout Ratio (DPR) (X1)

Dividend payout ratio (DPR) merupakan seberapa besar jumlah dividen yang dibayarkan oleh perusahaan kepada pemegang saham.. Dividend Payout Ratio (DPR) ini dapat dihitung dengan rumus sebagai berikut:

Dividend

Dividend Payout Ratio= Net Profit

\section{Dividend Yield (DY) (X2)}

Dividend Yield (DY) merupakan seberapa besar keuntungan atau imbal hasil dividen yang diberikan oleh perusahaan kepada pemegang saham. Dividend Yield (DY) ini dapat dihitung dengan rumus sebagai berikut:

Dividend per share

Dividend Yield = x 100

Market value per share

Teknik Analisis Data

Uji Asumsi klasik

Untuk memperoleh hasil regresi linier yang baik maka digunakan uji asumsi klasik.Uji asumsi klasik untuk menguji suatu model yang termasuk layak atau tidak layak digunakan dalam penelitian. Uji asumsi klasik yang digunakan dalam penelitian ini adalah sebagai berikut:

\section{Uji Normalitas}

Pengujian normalitas dalam penelitian ini digunakan dengan melihat normal probability plot yang membandingkan distribusi kumulatif dari data sesungguhnya dengan distribusi kumulatif dari distribusi normal. Sedangkan dasar pengambilan keputusan untuk uji normalitas data ada-

lah :
NIAGAWAN Vol 8 No 2 Juli 2019

Jika data menyebar di sekitar garis diagonal dan mengikuti arah garis diagonal atau grafik histogramnya menunjukkan distribusi normal, maka model regresi memenuhi asumsi normalitas.

Jika data menyebar jauh dari diagonal dan atau tidak mengikuti arah garis diagonal atau grafik histogramnya tidak menunjukkan distribusi normal, maka model regresi tidak memenuhi asumsi normalitas.

\section{Uji Multikolineartas}

Uji multikolineartas dilakukan untuk menguji ada tidaknya korelasi antara variable independen.Apakah terjadi korelasi maka dinamakan multikol, yaitu adanya masalah multikolinearitas.Model regresi yang baik seharusnya tidak terjadi korelasi diantara variable independenya. Model dikatakan terbatas dari multikolineartas jika:

Dengan melihat angka tolerance dan Variance Inflation Factor (VIF) hitungnya. Suatu model regresi dikatakan terbebas dari multikolineartas jika VIF nya tidak lebih dari 10 dan nilai toleransi disekitar 1 atau mendekati 1 .

Koefisien korelasi antar variable independen haruslah lemah. Nilai R2 yang menunjukan nilai yang lebih kecil dari pada koefisien korelasi simultan (R).

\section{Uji Heterokedastisitas}

Uji heterokedastisitas pada dasarnya bertujuan untuk menguji apakah dalam model regresi terjadi ketidaksamaan variance dari residual satu pengamatan ke pengamatan yang lain. Jika variance dari satu pengamatan ke pengamatan yang lain tetap, maka disebut Homokedastisitas. Model regresi yang baik seharusnya tidak terjadi heterokedastisitas.

Dasar pengambilan keputusan pada uji heterokedastisitas dengan melihat grafik scatterplot yakni: Jika ada pola tertentu, seperti titik-titik yang ada membentuk pola tertentu yang teratur (bergelombang, melebar kemudian menyempit), maka mengidentifikasi telah terjadi heterokedastisitas.

Jika tidak ada pola yang jelas, titik-titk menyebar diatas dan dibawah angka 0 pada sumbu Y, maka tidak terjadi heterokedastisitas.

\section{Uji Autokorelasi}

Uji autokorelasi bertujuan untuk menguji ada atau tidaknya kesalahan 
pengganggu pada periode $\mathrm{t}$ dengan kesalahan pengganggu pada periode t-1 (sebelumnya) dalam penelitian. Pengujian autokorelasi dilakukan dengan menggunakan uji DurbinWaston. Kriteria untuk terjadinya aautokorelasi yaitu:

Tabel 3 Keputusan Autokorelasi

\begin{tabular}{|c|c|c|}
\hline Keterangan & Keputusan & Jika \\
\hline $\begin{array}{l}\text { Tidak } \\
\text { autokorelasi } \\
\text { positif }\end{array}$ & Tolak & $\begin{array}{l}0<\mathrm{d} \\
<\mathrm{dL}\end{array}$ \\
\hline $\begin{array}{l}\text { Tidak } \\
\text { autokorelasi } \\
\text { positif }\end{array}$ & No decision & $\begin{array}{l}\mathrm{dL} \leq \mathrm{d} \leq \\
\mathrm{dU}\end{array}$ \\
\hline $\begin{array}{l}\text { Tidak ada } \\
\text { autokorelasi } \\
\text { negatif }\end{array}$ & Tolak & $\begin{array}{l}4-\mathrm{dL} \\
<\mathrm{d}<4\end{array}$ \\
\hline $\begin{array}{l}\text { Tidak ada } \\
\text { autokorelasi negatif }\end{array}$ & No decision & $\sum_{\mathrm{dL}}^{4-\mathrm{dU}} \mathrm{d} \leq 4$ \\
\hline $\begin{array}{l}\text { Tidak } \\
\text { autokorelasi }\end{array}$ & Tidak ditolak & $\begin{array}{l}\mathrm{dU}<\mathrm{d} \\
<4- \\
\mathrm{dU}\end{array}$ \\
\hline
\end{tabular}

Analisis Regresi Linier Berganda

Meregresi variable bebas ke variabel Y. Analisis regresi digunakan untuk mengetahui seberapa besar pengaruh variable $\mathrm{X}$ yaitu dividend payout ratio (DPR) dan dividend yield (DY) terhadap variabel Y (harga saham). Dalam penelitian ini analisis regresi yang digunakan adalah analisis regresi linier berganda dengan bentuk persamaan:

$\mathrm{Y}=\mathrm{a}+\mathrm{b} 1 \mathrm{X} 1+\mathrm{b} 2 \mathrm{X} 2+\mathrm{e}$

\section{Dimana :}

$$
\begin{array}{ll}
\mathrm{Y} & =\text { harga saham } \\
\mathrm{a} & =\text { konstanta } \\
\mathrm{b} & =\text { koefisien regresi } \\
\mathrm{X} 1 & =\text { dividend payout ratio (DPR) } \\
\mathrm{X} 2 & =\text { dividend yield (DY) } \\
\mathrm{e} & =\text { standard error }
\end{array}
$$

\section{Uji Hipotesis}

Uji t (Parsial)

Uji parsial atau koefisien regresi dimaksud untuk memastikan apakah variabel bebas (X1 dan X2) yang terdapat dalam persamaan tersebut secara individu berpengaruh terhadap nilai variabel terikat (Y). Caranya dengan melakukan pengujian terhadap koefisien regresi setiap variabel bebas dengan
NIAGAWAN Vol 8 No 2 Juli 2019

menggunakan uji t. Adapun rumus yang digunakan untuk menguji masing-masing hipotesis ini adalah dengan uji t parsial (Ridwan, 2011:125) yaitu:

$$
t=r_{x y} \frac{\sqrt{n-2}}{\sqrt{1-r^{2}}}
$$

Dimana :

$$
\begin{array}{ll}
\mathrm{t} & =\text { signifikan parsial } \\
\mathrm{r} & =\text { koefisien korelasi parsial } \\
\mathrm{n} & =\text { jumlah sampel/responden }
\end{array}
$$

Langkah-langkah pengujian untuk uji $\mathrm{t}$ adalah sebagai berikut:

Menentukan model hipotesis untuk Ho dan Ha.

Ho : bl $=0$, artinya secara parsial tidak terdapat pengaruh yang positif dan signifikan dari variabel bebas $(\mathrm{X})$ terhadap variable terikat $(\mathrm{Y})$. Sedangkan jika Ha : bl $\neq 0$, artinya secara parsial terdapat pangaruh yang positif dan signifikan dari variabel terikat (Y). Mencari nilai $\mathrm{t}$ tabel dengan cara menetukan tingkat kesalahan dan derajat kebebasan $(\mathrm{df})=\mathrm{n}-\mathrm{k}$, dimana $\mathrm{n}$ adalah jumlah sampel dan $\mathrm{k}$ adalah jumlah variable independen yang digunakan.

Menetukan Kriteria pengambilan keputusan.

Ho diterima jika t hitung $<\mathrm{t}$ tabel pada $\alpha=5 \%$

Ha diterima jika $t$ hitung $<\mathrm{t}$ tabel pada $\alpha=5 \%$

Uji Koefisien Determinasi (R2)

Uji ini digunakan untuk kontribusi variabel bebas yaitu dividend payout ratio (DPR) sebagai X1 dan dividend yield (DY) sebagai X2 terhadap harga saham (Y) sebagai variabel terikat. Untuk mengukur uji koefisien determinasi dapat digunakan rumus sebagai berikut :

$\mathrm{Kd}=\mathrm{R} 2 \times 100 \%$

\section{HASIL DAN PEMBAHASAN}

Uji Asumsi Klasik

Uji Normalitas

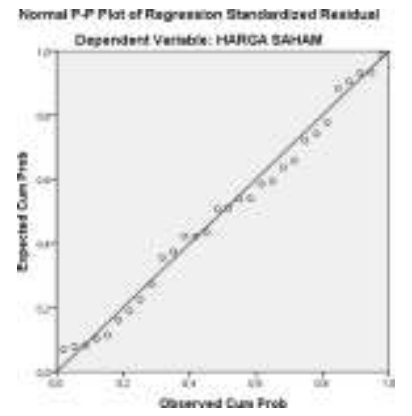

Gambar 2 Normal P-P Plot of Regresion Standarized Residual 
Pada Gambar 2 di atas terlihat bahwa titik-titik menyebar di sekitar garis diagonal dan mengikuti arah garis diagonal. Berdasarkan hasil tersebut, maka data dalam penelitian ini memiliki distribusi secara normal dan memenuhii uji normalitas data.

Uji Multikolinearitas

Tabel 4 Multikolinearitas

\begin{tabular}{|cc|c|c|}
\hline \multicolumn{2}{|c|}{ Model } & \multicolumn{2}{|c|}{ Collinearity Statistics } \\
\cline { 3 - 4 } & & Tolerance & VIF \\
\hline \multirow{2}{*}{1} & DPR &, 718 & 1,393 \\
& DY &, 718 & 1,393 \\
\hline
\end{tabular}

Berdasarkan tabel 4 di atas dapat dilihat nilai toleransi untuk DPR $(\mathrm{X} 1)=0,718$, DY $(\mathrm{X} 2)=$ 0,718 sedangkan VIF untuk DPR $(X 1)=1,393$, DY $(X 2)=1,393$. Hal ini menunjukkan bahwa VIF lebih kecil dari 10 dan nilai toleransi lebih besar daro 0,10. Maka dapat disimpulkan bahwa antar variabel bebas tidak terjadi multikolinearitas.

Uji Heterokedastisitas

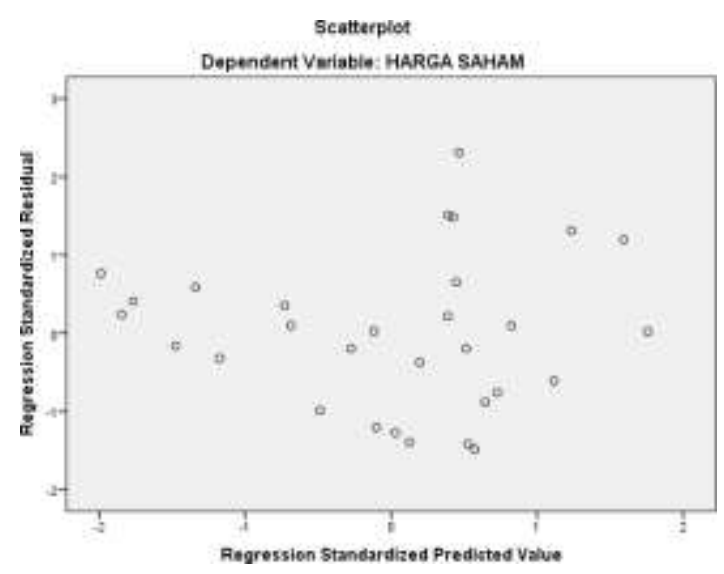

Gambar 3 Scatterplot Regresi Standar Residual

Pada Gambar 3 di atas menunjukkan bahwa titik-titik data menyebar disekitar angka nol dan tidak mengumpul di suatu titik. Penyebaran titik-titik data tersebut juga tidak membentuk suatu pola. Jadi dapat disimpulkan bahwa model regresi penelitian ini tidak mengalami permasalahan heterokedastisitas.
Uji Autokorelasi

NIAGAWAN Vol 8 No 2 Juli 2019

Tabel 5 Hasil Uji Autokorelasi

\begin{tabular}{|c|c|r|r|r|r|}
\hline $\begin{array}{r}\text { Mo } \\
\text { del }\end{array}$ & $\mathrm{R}$ & $\begin{array}{r}\mathrm{R} \\
\text { Squa } \\
\text { re }\end{array}$ & $\begin{array}{c}\text { Adjuste } \\
\mathrm{d} \mathrm{R} \\
\text { Square }\end{array}$ & $\begin{array}{c}\text { Std. } \\
\text { Error of } \\
\text { the } \\
\text { Estimat } \\
\mathrm{e}\end{array}$ & $\begin{array}{r}\text { Durbin- } \\
\text { Watson }\end{array}$ \\
\hline 1 & $\begin{array}{r}691 \\
\mathrm{a}\end{array}$ &, 441 &, 485 &, 48750 & 1,668 \\
\hline
\end{tabular}

Predictors: (Constant), DY, DPR

Dependent Variable: HARGA SAHAM

Dari tabel 5 terlihat bahwa nilai DurbinWaston yang didapat sebesar 1,668. Nilai ini akan dibandingkan oleh nilai tabel dengan derajat kepercayaan sebesar 5\% jumlah data (N) = 30 dan jumlah variabel eksogen (2) maka diperoleh nilai $\mathrm{dL}=1,284$ dan $\mathrm{dU}=1,567$. Nilai Durbin-Waston ini lebih besar daripada nilai dU $=1,567$ dan lebih kecil dari nilai (4-dU) 4-1,567 $=2,433$. Jadi dapat disimpulkan tidak ada masalah autokorelasi.

\section{Analisis Regresi Liniear Berganda}

Tabel 6 Hasil Uji Regresi Liniear Berganda

\begin{tabular}{|l|l|l|l|l|l|}
\hline Model & \multicolumn{2}{|l|}{$\begin{array}{l}\text { Unstandardized } \\
\text { Coefficients }\end{array}$} & $\begin{array}{l}\text { Standar } \\
\text { dized } \\
\text { Coefficie } \\
\text { nts }\end{array}$ & Sig. \\
\cline { 2 - 5 } & B & $\begin{array}{l}\text { Std. } \\
\text { Error }\end{array}$ & Beta & & \\
\hline $\begin{array}{l}\text { (Const } \\
\text { ant) } \\
\text { DPR }\end{array}$ & 6,416 & 5,010 & & 3,69 &, 000 \\
DY & 1,242 &, 554 &, 444 & 2,24 \\
1,958 &, 748 &, 551 & 2,78 &, 033 \\
\hline
\end{tabular}

a. Dependent Variable: HARGA SAHAM

Dari hasil SPSS diatas dapat dijelaskan sebagai berikut:

$\mathrm{Y}=6,416+1,242 \mathrm{X} 1+1,958 \mathrm{X} 2+\mathrm{e}$

Konstan sebesar 6,416 menyatakan bahwa jika tidak ada variabel $\mathrm{X}$, maka Harga Saham adalah sebesar 6,416 dengan asumsi faktor lain konstan. Koefisien regresi variabel X1 sebesar 1,242 menyatakan bahwa setiap terjadi perubahan DPR 1\% akan mempengaruhi Harga Saham sebesar 1,242 dengan asumsi faktor lain konstan. Koefisien regresi variabel X2 sebesar 1,958 menyatakan bahwa setiap terjadi peningkatan DY $1 \%$ akan mempengaruhi 
NIAGAWAN Vol 8 No 2 Juli 2019

Harga Saham sebesar 1,958 dengan asumsi faktor lain konstan.

Uji Hipotesis

Tabel 7 Hasil Uji t (Parsial)

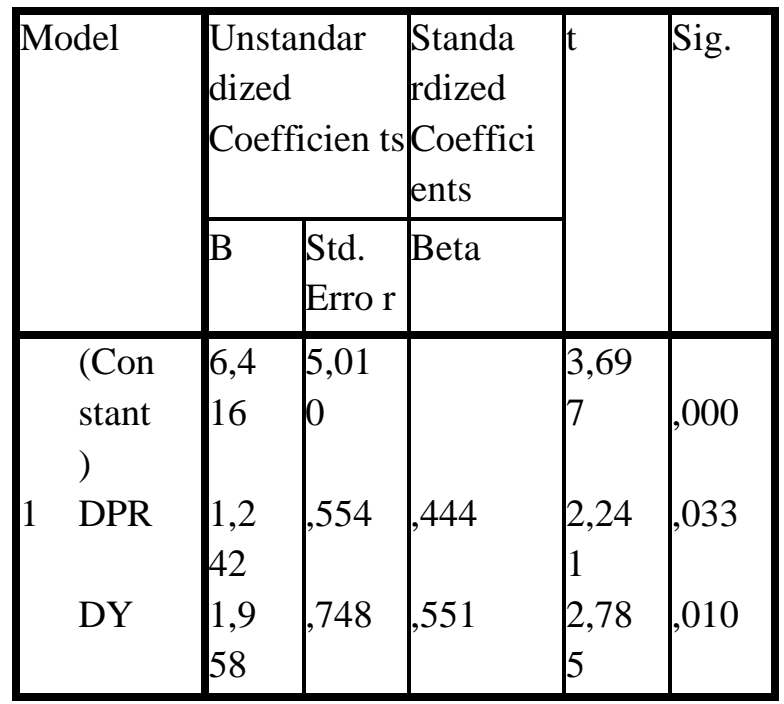

a. Dependent Variable: HARGA SAHAM

Dari tabel 4.8 di atas dapat dijelaskan bahwa:

DPR berpengaruh positif dan signifikan terhadap Harga Saham dengan nilai thitung $=2,241>$ ttabel $=2,052$ dan probabilitas 0,033 pada tingkat signifikan 5\%. Hal ini berarti semakin meningkat DPR, maka semakin meningkat Harga Saham Perusahaan sub sektor otomotif dan komponen. DY berpengaruh positif dan signifikan terhadap Harga Saham dengan nilai thitung $=2,785>$ ttabel $=2,052$ dan probabilitas 0,010 pada tingkat signifikan $5 \%$. Hal ini berarti semakin meningkat DY, maka semakin meningkat Harga Saham Perusahaan sub sektor otomotif dan komponen.

Uji Koefisien Determinasi (Uji R2)

Tabel 8 Koefisien Determinasi

\begin{tabular}{|l|l|l|l|l|}
\hline $\begin{array}{c}\text { Mo } \\
\text { del }\end{array}$ & \multicolumn{1}{|c|}{$\mathrm{R}$} & \multicolumn{1}{|c|}{$\mathrm{R}$} \\
Squa re & $\begin{array}{c}\text { Adjuste d R } \\
\text { Square }\end{array}$ & $\begin{array}{c}\text { Std. Error } \\
\text { of the } \\
\text { Estimat e }\end{array}$ \\
\hline 1 &, 491 &, 241 &, 185 & $\begin{array}{l}67,4875 \\
0\end{array}$ \\
\hline
\end{tabular}

Predictors: (Constant), DY, DPR

Dependent Variable: HARGA SAHAM

Dari tabel diatas, angka $\mathrm{R}$ sebesar 0,491 menunjukkan bahwa korelasi atau hubungan yang kuat antara variabel independen (DPR dan DY) dengan variabel dependen (Harga Saham). Koefisien determinan (R square) sebesar 0,241. Nilai 0,241 ini menunjukkan bahwa variabel
Harga Saham (Y) dapat dijelaskan oleh variabel DPR (X1) dan DY (X2) secara bersama-sama sebesar $24,1 \%$ dan sisanya $75,9 \%$ dipengaruhi oleh variabel lain diluar model penelitian.

\section{KESIMPULAN DAN SARAN Kesimpulan}

Berdasarkan hasil analisis data dan pembahasan yang telah dilakukan dalam penelitian ini, maka dapat diambil kesimpulan sebagai berikut: (1) Dividend payout ratio memiliki pengaruh terhadap harga saham dengan $\mathrm{t}$ hitung lebih besar dari $\mathrm{t}$ tabel $(2,241$ $>2,052$ ) dengan signifikansi $0,033<0,05$. (2) Pembayaran dividen (DPR) perusahaan yang naik mempengaruhi harga saham perusahaan. (3) Dividend yield memiliki pengaruh terhadap harga saham dengan $\mathrm{t}$ hitung lebih besar dari $\mathrm{t}$ tabel $(2,785>2,052)$ dengan signifikansi $0,010<$ 0,05 . Kemampuan perusahaan dalam menjamin pembagian imbal hasil (DY) kepada para pemegang saham mempengaruhi naiknya harga saham perusahaan.

\section{Saran}

Bagi perusahaan yang go public di Bursa Efek Indonesia diharapkan tetap mempertahankan pembagian dividen setiap tahunnya, karena dividen merupakan sinyal kuat bagi para investor yang hendak menanamkan modalnya pada perusahaan. Bagi perusahaan yang go public di Bursa Efek Indonesia diharapkan perusahaan mampu meningkatkan laba serta menjaga kondisi laba perusahaan, sehingga perusahaan dapat membagikan dividen setiap tahunnya dari hasil laba perusahaan. Bagi perusahaan yang go public di Bursa Efek Indonesia diharapkan tetap mempertahankan pembagian DPR dan DY dalam perusahaan, karena DPR dan Dy merupakan sinyal kuat bagi para investor yang hendak menanamkan modalnya pada perusahaan. Bagi investor yang hendak menanamkan modalnya pada perusahaan yang go public di Bursa Efek Indonesia diharapkan mempertimbangkan nilai DPR dan DY sebagai pertimbangan jangka panjang. Untuk peneliti selanjutnya disarankan untuk memperluas objek penelitian tidak hanya pada perusahaan sub sektor otomotif dan komponen saja dan disarankan untuk menggunakan sampel yang lebih luas. Peneliti selanjutnya disarankan untuk menambah variabel independen lain yang dapat mempengaruhi harga saham. 


\section{REFERENSI}

Abdul, Halim. 2015. Analisis Investasi di Aset Keuangan. Jakarta: MitraWacana Media.

Abi, Fransiskus Paulus Paskalis. 2016. SemakinDekatdenganPasar Modal Indonesia. Yogyakarta: CV Budi Utama.

Azis, Musdalifah. 2015. Manajemen Investasi Fundamental, Teknikal, Perilaku Investor dan Return Saham. Yogakarta: CV Budi Utama.

Hadi, Nor. 2013. Pasar Modal. Yogyakarta: Graha Ilmu.

Hanafi, Mahmud M. 2013. Manajemen Keuangan. Edisi Pertama. Yogyakarta: BPFE.

Hariyani, Iswi Serfianto. 2010. Buku Pintar Hukum Bisnis Pasar Modal. Jakarta: Trans Media.

Hery. 2015. Pengantar Akuntansi Comprehesi ve Edition. Jakarta: PT Grasindo.

Jogiyanto, H. 2014. Teori Portofolio dan Analisis Investasi. Edisi Ke 10. Yogyakarta: BPFE.

Mulyawan, Seia. 2015. Manajemen Keuangan. Bandung: Pustaka Setia.

Murhadi, Warner R. 2013. Analisis Laporan Keuangan, Proyeksi dan Valuasi Saham. Jakarta: Salemba Empat.

Musthafa. 2017. Manajemen Kuangan. Edisi Pertama. Yogyakarta: CV Andi Offset.

Sartono, R. Agus. 2010. Manajemen Keuangan Teori dan Aplikas. Edisi 4. Yogyakarta: BPFE.

Sugiyono. 2013. Metode Penelitian Bisnis. Bandung: Alfabeta.

Tandelilin, E. 2010. Portofolio dan Investasi: Teori dan Aplikasi. Edisi Pertama. Yogyakarta: Kansius.
NIAGAWAN Vol 8 No 2 Juli 2019

Warsono. 2012. Manajemen Keuangan Perusahaan, Edisi Tiga Jilid 1. Malang: Bayu Media Publishing.

Yudiana, Fetria Eka. 2013. Dasar- Dasar Manajemen Keuangan. Yogyakarta: Ombak Dua. 